\title{
THOMAS REID
}

\section{ESSAYS ON THE ACTIVE POWERS OF MAN}




\title{
THE EDINBURGH EDITION OF THOMAS REID
}

\author{
General Editor \\ Knud Haakonssen
}

Thomas Reid (1710-96) is an original philosopher of lasting importance and a central figure in the Scottish Enlightenment. The Edinburgh Edition makes available the first critical editions of the philosophical treatises that established Reid as the great critic of David Hume, as well as extensive, previously unpublished manuscript materials which show Reid as a strikingly versatile Enlightenment thinker. Introductions and notes by an international group of specialists ensure the volumes are equally valuable to students and scholars.

Volumes available in the series

1 Thomas Reid on the Animate Creation: Papers Relating to the Life Sciences, (ed.) Paul Wood

2 An Inquiry into the Human Mind on the Principles of Common Sense, (ed.) Derek R. Brookes

3 Essays on the Intellectual Powers of Man, (eds)

Derek R. Brookes and Knud Haakonssen

4 The Correspondence of Thomas Reid, (ed.) Paul Wood

5 Thomas Reid on Logic, Rhetoric and the Fine Arts: Papers on the Culture of the Mind, (ed.) Alexander Broadie

6 Thomas Reid on Practical Ethics, (ed.) Knud Haakonssen

7 Essays on the Active Powers of Man, (eds) Knud Haakonssen and James A. Harris

Forthcoming volumes in the series

8 Thomas Reid on Society and Politics, (eds) Knud Haakonssen and Paul Wood

9 Thomas Reid on Mathematics and Natural Philosophy, (ed.) Paul Wood

10 Thomas Reid and the University, (eds) Alexander Broadie and Paul Wood 


\section{THOMAS REID}

\section{ESSAYS ON THE ACTIVE POWERS OF MAN}

EDITED BY

Knud Haakonssen and

James A. Harris 
(C) editorial matter and organization Knud Haakonssen and James A. Harris, 2010

(C) in this edition Edinburgh University Press, 2010

Edinburgh University Press Ltd

22 George Square, Edinburgh

www .euppublishing.com

Typeset in 10.5/13.5pt Times

by Norman Tilley Graphics, Northampton,

and printed and bound in Great Britain

by CPI Antony Rowe, Chippenham and Eastbourne

A CIP record for this book is

available from the British Library

ISBN 9780748617081 (hardback)

The right of Knud Haakonssen and James A. Harris to be identified as authors of the editorial matter has been asserted in accordance with the Copyright, Designs and Patents Act 1988. 